\title{
Developing an Emotional Intelligence Program Training and Study Its Effectiveness on Emotional Intelligence of Adolescents with Emotional and Behavioral Problems That Living in Single Parent Families
}

\author{
Farzaneh Motamedi ${ }^{1}$, Bagher Ghobari-Bonab ${ }^{2}$, Ahmad Beh-pajooh ${ }^{2}$, Mohsen Shokoohi Yekta ${ }^{2}$ \& Gholam Ali Afrooz ${ }^{2}$ \\ ${ }^{1}$ Psychology and Exceptional children education, University of Tehran, Tehran, Iran \\ ${ }^{2}$ Faculty of Education and Psychology, University of Tehran, Tehran, Iran \\ Correspondence: Farzaneh Motamedi, University of Tehran, Tehran, Iran. E-mail: f.motamedi@gmail.com
}

Received: December 4, 2016

Accepted: December 25, $2016 \quad$ Online Published: January 5, 2017

doi:10.5539/jel.v6n2p101

URL: http://dx.doi.org/10.5539/jel.v6n2p101

\begin{abstract}
Development of children and adolescents' personality is strongly affected by their parents, and absence of one of them has an undesirable effect on their development, and makes them vulnerable to later psychological disorders and behavioral problems. The purpose of this study was to develop an emotional intelligence training program and to evaluate its effectiveness on increasing emotional intelligence of adolescents with emotional and behavioral problems that living in single parent families. The study utilized a quasi-experimental research method with pretest-posttest and follow-up with control group. The sample of the study selected by a purposive sampling method and 11 students in the experimental group and 12 students in the control group were among the adolescents with emotional and behavioral problems that living in single parent families. This program was offered through workshop which consisted of 10 sessions, two hours per session. The instruments which were used in this study included Child Behavior Checklist (CBCL), and Youth Self Report (YSR), and Bar-on Adolescents' Emotional Intelligence Scale. The obtained data was analyzed using Repeated Measures of Analysis of Variance, which showed that emotional intelligence training program could significantly increase emotional intelligence in adolescents with emotional and behavioral problems in single parent families.
\end{abstract}

Participating in the workshop, has led to increasing the emotional intelligence of adolescents with emotional and behavioral problems that living in single parent.

Keywords: emotional intelligence training program, adolescents with emotional and behavioral problem, single parent

\section{Introduction}

Development of personality in children is strongly influenced by parents. The absence of one parent or both will have adverse impacts on their growth and will make them susceptible to mental illness or behavioral disorders. The absence of father may have direct and indirect impacts on adolescents. Adolescence is a period during which rapid changes occur in biological, behavioral, cognitive, and emotional aspects and those adolescents with emotional and behavioral problems may face more obstacles during the time of coping with the rapid changes of adolescence. As the most significant issue in them is inability to sustain satisfactory emotional and intimate relationships with other people (Nelson, 2013). It is obvious that emotions play a vital role in the organization, expression of social experiences, creating and directing energy to do activities and emotional intelligence is responsible for ability to identify and manage these emotions and reasoning and problem solving. The first coherent theory on emotional intelligence was introduced by Meyer and Salovi (Bar-On, 2010). Subsequently, various theories were developed in this field. There are five categories of emotional intelligence in Bar-on model and it is a broader and more comprehensive compared to other emotional intelligence models: intrapersonal skills: The ability to learn and understand their emotions and includes the following components of self-esteem, assertiveness, self-fulfillment, independence, self-awareness. Interpersonal skills: the ability to know and understand the emotions of others which includes empathy and social responsibility. Adaptability: ability to change feelings and reality testing which includes problem solving and flexibility. Stress management: the 
ability to cope with stress and emotion regulation which includes impulse control and taking stress tolerance. General mood: it refers to expressing positive emotions and includes optimism and happiness (Gayathri \& Meenakshi, 2013). Emotional intelligence has been the ability to predict the different variables in empirical research by contributing to further research on emotional intelligence. Some researchers (Durlak, Weissberg, Dymnicki, Taylor, \& Schellinger, 2011; Nelis, Quoidbach, Mikolajczak, \& Hansenne, 2009; Nelis, Kotsou, Quoidbach, Hansenne, Weytens, Dupuis, \& Mikolajczak, 2011; Saadi, Honarmand, Najarian, Ahadi, \& Askari, 2012; Schutte, Malouff, \& Thorsteinsson, 2013) have examined the effectiveness of teaching emotional intelligence and have confirmed their results which state emotional intelligence training has improved emotional intelligence significantly. In this regard, various training programs have been developed to foster emotional and social intelligence based on bar-on theory and it has been demonstrated that emotional and social intelligence have had a significant increase after participating in training program and Bar-on model components can be taught and learned (Freedman, 2003; Orme, 2003). It overlaps with the personality traits such as assertiveness, empathy, trust, self-regulation which has led to a massive agreement about the power of this model to predict the success and consistency (Sternberg, 2000).

Researchers have shown that insufficiency of emotional intelligence is linked to irregularities in problematic behaviors in adolescents (Nawi \& Redzuan, 2011). They are rejected or isolated from their friends at school and are facing more violent behaviors (Esturgo-Deu \& Sala-Roca, 2010). While students with higher scores on emotional intelligence, had less unjustified absences and have been less dropped out of school (Petrides, Frederickson, \& Furnham, 2004). Song believes that emotional intelligence training is necessary because of the current social conditions, increased divorce, single parent families and increased social problems. In his opinion, when parent do not pay attention to the emotional needs of children because of their personal problems, children will be have poor emotional intelligence and more behavior problems (Wolfe \& Mash, 2006). Living in unsuitable environmental conditions can be sources of stress for teens and have a negative impact on emotional health and their behavior. Various studies also have reported that children of single-parent families caused by divorce has low self-esteem and empathy, aggression, disruptive behavior, conflict (DeLeire \& Kalil, 2001), rising delinquency and school problems, use of drugs and alcohol and are failing in school (Carlson \& Corcoran, 2001; Siu, 2009). The vulnerability of adolescents and absence of the father in single-parent families on the one hand, the risk of emotional problems and behavior and the disability to express and manage emotions on the other hand, all aspects of individual and social life teenager affect. Since a person's ability to cope in life and proper functioning depends on his emotional capabilities, emotional intelligence training to reinforce personal efficiency and improve interpersonal relationships teenagers is essential that can partly solve or compensate the problems of this group (Ciairano, Bosma, Miceli, \& Settanni, 2008).

\section{Method}

\subsection{Statistical Population, Sample, Research Conducting Procedure}

This study is a quasi-experimental research with pre-test, post-test and follow-up with the control group. The population included in this study were adolescents with an age range of 13 to 16 with emotional and behavioral problems in Tehran in academic year 2013-2014 in single-parent families (fatherless due to parental divorce) who were covered by welfare organization. The sample group consisted of 28 students selected through purposeful selection and randomization of subjects and drop of subjects was 11 subjects in the experimental group and 12 subjects in the control group. Research data were collected in three stages (pre-test, post-test and follow-up) and analyzed using Repeated Measures of Analysis of Variance.

\subsection{Instruments}

\subsubsection{Researcher Made Need Assessment Questionnaire}

Researcher-made questionnaire was used in order to identify the skills required to design training program. Semi-structured interviews were conducted with mothers of participants to develop questionnaire and identify the needs of their children. The obtained results were used to design need assessment questionnaire which was filled by eight adolescents with emotional and behavioral problems. This questionnaire consists of eighteen propositions which contained fifteen bar-on emotional intelligence skills. Scoring was based on five-point Likert scale from very much to none (0-5) and frequency of each skill was calculated. Eight skills of intended skills and conflict management skills which were added to Need Assessment questionnaire based on background and interviews with parents had the highest frequency percentage which was selected as the framework of emotional intelligence training program. 


\subsubsection{Questionnaires Based on Achenbach System}

Child Behavior Checklist (CBCL) and Youth Self Report (YSR) were used in this study to measure emotional and behavioral problems children from 11 to 18 years old. Child Behavior Checklist factor structure was evaluated in a sample of 631 8-18 year old American children and young people with severe emotional disorders using confirmatory factor (Achenbach \& Rescorl, 2011). Minaee (2005) also evaluated factor structure of the child behavior checklist using confirmatory factor analysis and the results of his research showed that Achenbach factor model has a good fit with data. Minaee (2006) calculated internal consistency of child behavior checklist and adolescent self-report from using Cronbach's alpha in another study and obtained a range of internal consistency coefficients from 0.32 to 0.67 .

\subsubsection{Bar-On Emotional Intelligence Questionnaire}

Bar-on Emotional Intelligence instrument is a self-report instrument for measuring emotional intelligence based on Bar-on model and it is made for 7 to 18 years old individuals and includes both short and long forms, short form contains of 30 questions and long form includes 60 questions in 4-point Likert scale which has been rated from very little to always. The long form has been used in this study. Bar-On and Parker (2000) reported the reliability of the subscales and the whole questionnaire to be from 0.65 to 0.90 for girls. Its reliability coefficient has been reported to be from 0.77 to 0.89 through retest with period of 3 weeks between pre-test and post test. The Construct validity has been evaluated with evaluation of correlation between this questionnaire (teenagers) and adult emotional intelligence questionnaire. High and significant correlation has been reported to be from 0.56 for subscale of interpersonal relations to 0.88 for the subscale of general mood. Al-Seyyed et al. (2013) examined the psychometric properties of the short form list of emotional intelligence young children 8 to 10 years in Oman and reported that Oman validity and reliability of the questionnaire for children is acceptable. A significant relationship between emotional intelligence subscales long-form and cognitive intelligence and personality self-report is obtained (Shuler, 2004). There are good evidences in examination of psychometric properties of long form emotional intelligence Bar-on questionnaire for teenagers in Tehran about confirmation of reliability with range of coefficients from 0.80 to 0.92 by Cronbach's alpha and 0.74 to 0.90 obtained by Spearman Brown method. Also some evidences were obtained in case of Face validity and construct validity using correlation between the factors were observed coefficients had a range between 0.56 and 0.76 (Beh-Pajooh, Shokoohi Yekta, Motamedi, Afrooz, \& Ghobari Bonab, 2015). The test scores Includes a total score of emotional intelligence and five subscales, including intrapersonal, interpersonal, adaptability, stress management and general mood and score includes Positive impression and Inconsistency index is scored from 1 to 4 .

\subsection{Introduction on Emotional Intelligence Training Programs}

Given the importance and need assessment questionnaire to highlight the nine skills through subjects, ten-session program based on the theory of bar-on was designed and implemented the overall list of educational sessions as Table 1.

Table 1. Emotional intelligence training program outline

\begin{tabular}{|c|c|c|c|}
\hline Session & Subject & Target & Materials, methods and implementation \\
\hline 1 & $\begin{array}{l}\text { Emotional } \\
\text { self-awareness }\end{array}$ & $\begin{array}{l}\text { The purpose of this session is to increase the } \\
\text { ability to recognize their emotions and others } \\
\text { identify their unique, capabilities, weaknesses } \\
\text { and their needs. }\end{array}$ & $\begin{array}{l}\text { Through the provision of various worksheets } \\
\text { and various scenarios, identifying their feelings } \\
\text { and others, to recognize the different emotional } \\
\text { states, identify strengths and interests were } \\
\text { practiced. }\end{array}$ \\
\hline 2 & Empathy & $\begin{array}{l}\text { This session will help participants gain the } \\
\text { ability to understand others' feelings. }\end{array}$ & $\begin{array}{l}\text { Scenarios and different activities to practice } \\
\text { these skills were offered. Such as your } \\
\text { classmates when going to school fall down on } \\
\text { stairs... his leg will be injured and cannot } \\
\text { attend in class... }\end{array}$ \\
\hline 3 & Assertiveness & $\begin{array}{l}\text { The purpose of this session will help } \\
\text { participants to increase the ability, beliefs and } \\
\text { thoughts openly and defend their legitimate } \\
\text { skills taught in a constructive and non-violent } \\
\text { and aggressiveness. }\end{array}$ & $\begin{array}{l}\text { In this session passive behavior, aggressive, } \\
\text { bold and their characteristics through } \\
\text { discussions, presentations worksheet, theater } \\
\text { and educational clip were defined. }\end{array}$ \\
\hline
\end{tabular}




\begin{tabular}{|c|c|c|c|}
\hline 4 & $\begin{array}{l}\text { Interpersonal } \\
\text { relationships }\end{array}$ & $\begin{array}{l}\text { The purpose of this session to increase the } \\
\text { ability to establish and maintain satisfactory } \\
\text { bilateral relations that are characterized by } \\
\text { intimacy and exchange of emotions. }\end{array}$ & $\begin{array}{l}\text { Different forms of communication through the } \\
\text { presentation of papers, group games and } \\
\text { activities for the practical exercises. }\end{array}$ \\
\hline $\begin{array}{l}5 \\
6\end{array}$ & $\begin{array}{l}\text { Anger and impulse } \\
\text { control }\end{array}$ & $\begin{array}{l}\text { The purpose of this session acceptability of } \\
\text { aggressive impulses, restraint and control anger. }\end{array}$ & $\begin{array}{l}\text { The definition of anger and aggression, anger } \\
\text { triggers, ways of dealing with it, or relaxation } \\
\text { techniques for calming the mind by providing } \\
\text { worksheets and practical activities. }\end{array}$ \\
\hline 7 & Problem solving & $\begin{array}{l}\text { In this session participants can identify the } \\
\text { problem and define, create and implement } \\
\text { effective solutions. }\end{array}$ & $\begin{array}{l}\text { In this session presentation of papers, practical } \\
\text { activities were the main stages of problem } \\
\text { solving. }\end{array}$ \\
\hline 8 & stress management & $\begin{array}{l}\text { In this session ability to withstand adverse } \\
\text { events and stressful situations without having } \\
\text { feelings tolerance against failure. }\end{array}$ & $\begin{array}{l}\text { In this session by presentation of papers, } \\
\text { practical activities, the effect of stress on the } \\
\text { body, thoughts, feelings, and behavior are } \\
\text { explained. }\end{array}$ \\
\hline 9 & $\begin{array}{l}\text { Conflict } \\
\text { management }\end{array}$ & $\begin{array}{l}\text { During the session the administration the ability } \\
\text { to identify a way inconsistent with disabilities, } \\
\text { fair and efficient are discussed. }\end{array}$ & $\begin{array}{l}\text { The definition of conflict, because conflict is } \\
\text { positive, negative causes of conflict, the } \\
\text { consequences of conflict resolution, conflict } \\
\text { resolution styles and how to use it will be } \\
\text { becomes clear. }\end{array}$ \\
\hline 10 & Optimism & $\begin{array}{l}\text { The purpose of this session is the ability to see } \\
\text { the lighter side of life and maintain a positive } \\
\text { attitude, even in the face of disagreements and } \\
\text { problems. }\end{array}$ & $\begin{array}{l}\text { Educational clips, worksheets, scenarios and } \\
\text { practical activities are educational tools this } \\
\text { session. }\end{array}$ \\
\hline
\end{tabular}

\section{Results}

In the present study, the average age of the experimental group is 14.36 and with a standard deviation 1.12 and the control group 14.18 with standard deviation 16.1 .

Table 2. IQ characteristics and participants disorders and parental divorce years

\begin{tabular}{cccc}
\hline Variable & Class & Experimental & Control \\
\hline \multirow{2}{*}{ IQ } & $>100$ & 9 & 12 \\
& $<100$ & 2 & 0 \\
Disorder & affective & 6 & 3 \\
& anxiety & 5 & 6 \\
Divorce years & Under 5 & 5 & 6 \\
& Between 5 to 10 & 5 & 0 \\
\hline
\end{tabular}

Table 3 indicates increase in the means in almost all subscales of the experimental group after participating in training (post-test) and a slight decrease in some of the subscales in the follow-up. In other words members of the experimental group after the intervention program, there have reported more emotional abilities. However, almost no one in the control group between pre-test and post-test scale does not show a significant change and this trend was seen between posttest and follow-up in most subscales. 
Table 3. Descriptive data subscales of emotional intelligence questionnaire

\begin{tabular}{|c|c|c|c|c|c|c|c|c|c|}
\hline Subscales & Group & Phase & Mean & SD & Subscales & Group & Phase & Mean & SD \\
\hline \multirow{6}{*}{ Intrapersonal } & \multirow{6}{*}{ experimental } & pretest & $9 / 36$ & $2 / 11$ & \multirow{6}{*}{ Stress management } & \multirow{3}{*}{ experimental } & pretest & $18 / 36$ & $3 / 12$ \\
\hline & & posttest & 12 & $2 / 53$ & & & posttest & $37 / 27$ & $2 / 68$ \\
\hline & & follow-up & $10 / 91$ & $2 / 55$ & & & follow-up & 21 & $2 / 90$ \\
\hline & & pretest & $9 / 50$ & $2 / 15$ & & \multirow{3}{*}{ control } & pretest & $16 / 50$ & $1 / 98$ \\
\hline & & posttest & $12 / 17$ & $2 / 12$ & & & posttest & 39 & $1 / 54$ \\
\hline & & follow-up & $9 / 50$ & $2 / 15$ & & & follow-up & $16 / 50$ & $1 / 98$ \\
\hline \multirow{6}{*}{ Interpersonal } & \multirow{3}{*}{ experimental } & pretest & $23 / 27$ & $1 / 74$ & \multirow{6}{*}{ General mood } & \multirow{3}{*}{ experimental } & pretest & $22 / 91$ & $3 / 24$ \\
\hline & & posttest & $25 / 82$ & $2 / 71$ & & & posttest & $27 / 91$ & $2 / 02$ \\
\hline & & follow-up & $25 / 91$ & $2 / 55$ & & & follow-up & $26 / 45$ & $2 / 42$ \\
\hline & & pretest & $24 / 25$ & $3 / 91$ & & \multirow{3}{*}{ control } & pretest & $24 / 58$ & $2 / 61$ \\
\hline & control & posttest & $24 / 25$ & $3 / 91$ & & & posttest & $25 / 75$ & $3 / 02$ \\
\hline & & follow-up & $24 / 25$ & $3 / 91$ & & & follow-up & $24 / 58$ & $2 / 61$ \\
\hline \multirow{6}{*}{ Adaptability } & & pretest & 11 & $1 / 48$ & \multirow{6}{*}{ Positive impression } & \multirow{3}{*}{ experimental } & pretest & $9 / 36$ & $1 / 12$ \\
\hline & experimental & posttest & $11 / 82$ & $1 / 72$ & & & posttest & $10 / 45$ & $1 / 51$ \\
\hline & & follow-up & $11 / 82$ & $1 / 72$ & & & follow-up & $10 / 45$ & $1 / 64$ \\
\hline & & pretest & $12 / 58$ & $2 / 78$ & & \multirow{3}{*}{ control } & pretest & $9 / 33$ & $1 / 30$ \\
\hline & control & posttest & $12 / 58$ & $2 / 78$ & & & posttest & $9 / 33$ & $1 / 30$ \\
\hline & & follow-up & $12 / 58$ & $2 / 78$ & & & follow-up & $9 / 33$ & $1 / 30$ \\
\hline
\end{tabular}

Correctness of assumptions including absence of outlier variables and cases, normality, absence of singularity, multicollinearity and equality of variances of dependent variables were evaluated before performing Repeated Measures of Analysis of Variance on the data of emotional intelligence questionnaire (Meyers, Gamst, \& Guarino, 2006). Ensuring about absence of outlier variables was done before doing any analysis. Shapiro and Wilk test was used to evaluate normality due to the fact of having less than 50 subjects. Shapiro and Wilk statistic is not significant at a level of less than 0.001 or all the variables.

Analysis to compare two experimental and control groups in three measuring stages based on subscales of emotional intelligence questionnaire led to the results of Table 4 which shows changes in profiles of emotional intelligence in both experimental and control groups (Between-group factor) regardless of the time (of the group) are not significant. But the profile changes in the factors of time and regardless of the operating groups, based on multivariate Wilk significant differences were found. The size of the effect of the time factor $99 / 0$ is obtained based on the classification Cohen (1988) was in the high range. The interaction of time and also group factors was significant. This finding suggests that trend profiles of the two experimental and control groups were significantly different from each other is measured in three stages.

Table 4. Multivariate analysis of variance comparison mean of sub-scales in experimental and control groups in three measurements

\begin{tabular}{llllllll}
\hline Sources Change & Type of test & Value & F ratio & $\begin{array}{l}\text { Degrees of freedom } \\
\text { Hypothesis }\end{array}$ & $\begin{array}{l}\text { Degrees of freedom } \\
\text { Error }\end{array}$ & Level Significant & Size Effect \\
\hline Group & Wilk & $0 / 63$ & $1 / 57$ & 6 & 16 & $0 / 22$ & $0 / 37$ \\
Time & Wilk & $0 / 002$ & $430 / 67$ & 11 & 11 & $0 / 0005$ & $0 / 99$ \\
Time $\times$ Group & Wilk & $0 / 004$ & $264 / 40$ & 11 & 11 & $0 / 0005$ & $0 / 99$ \\
\hline
\end{tabular}


Then, to determine the variation between in three stages and effect of the time factor, this aims at testing within subject effect. It is worth noting that this test requires consideration of equality between three stages error covariance matrices and Mauchly's Test of Sphericity. Mauchly's Test of Sphericity index is significant for all subscales. Thus, the assumption of equal variance matrices error cannot be considered for the present data. Thus, there is the need to consider and report test results within-subjects in conditions where the assumption is not correct. Greenehouse-Gasser index was used due to the fact that assumption of Mauchly's Test of Sphericity for evaluation of significant $\mathrm{F}$ ratio and the problem of equality of variance to compare groups is resolved by regulating the degrees of freedom.

The results of the tests within-subjects effect in Table 5 and significant effect of time as well as time and group shows that among the variables in the study, can be a linear combination of variables which can determine profile changes of groups based on time factor as well as interaction of time and group and determine the resulting differences. Following up analysis to achieve variables which can enter this combination of variables requires evaluation of one-way analysis test results for comparison of variables between the three measurements.

Table 5. Multivariate test within-subjects affect mean sub-scales in three measurements

\begin{tabular}{cccccccc}
\hline Independent variable levels & $\begin{array}{c}\text { Type of } \\
\text { test }\end{array}$ & Value & F ratio & $\begin{array}{c}\text { Degrees of } \\
\text { freedom } \\
\text { Hypothesis }\end{array}$ & $\begin{array}{c}\text { Degrees of } \\
\text { freedom } \\
\text { Error }\end{array}$ & Level Significant & Size Effect \\
\hline Time & Wilk & $0 / 01$ & $50 / 50$ & 12 & 74 & $0 / 0005$ & $0 / 89$ \\
Time $\times$ Group & Wilk & $0 / 19$ & $8 / 11$ & 12 & 74 & $0 / 0005$ & $0 / 57$ \\
\hline
\end{tabular}

Results of Table 6 show that all subscales based on time factor and interaction of time and group have a significant $\mathrm{F}$ ratio at level of significance of $\mathrm{P}>0.05$. This means that all averages of subscales of emotional intelligence questionnaire have the ability to be present in the intended linear combination for determination of differences both for time factor and the interaction between time and group at the significance level of $\mathrm{P}<0.05$. Also the subscales of stress management, Intrapersonal skills and general mood are more important than other subscales for determination of changes in time and subscales of Interpersonal skills and General mood more important than other subscales (due to higher effect sizes) for determination of changes obtained from interaction between time and group.

Table 6. ANOVA comparison means sub-scales in three measurements

\begin{tabular}{|c|c|c|c|c|c|}
\hline Resource & Subscale & Third type of squares & $\begin{array}{l}\text { Degrees of } \\
\text { freedom }\end{array}$ & F ratio & $\begin{array}{r}\text { Level } \\
\text { Significant }\end{array}$ \\
\hline \multirow{6}{*}{ Time } & Intrapersonal & $85 / 38$ & $1 / 24$ & $37 / 48$ & $0 / 0005$ \\
\hline & Interpersonal & $25 / 71$ & $1 / 07$ & $16 / 16$ & $0 / 0005$ \\
\hline & Adaptability & $2 / 56$ & 1 & $10 / 57$ & $0 / 0004$ \\
\hline & Stress management & $616 / 54$ & $1 / 10$ & $48 / 07$ & $0 / 0005$ \\
\hline & General mood & $109 / 94$ & $1 / 31$ & $31 / 95$ & $0 / 0005$ \\
\hline & Positive impression & $4 / 55$ & $1 / 54$ & $13 / 14$ & $0 / 0005$ \\
\hline \multirow{6}{*}{$\begin{array}{l}\text { Time } \times \\
\text { Group }\end{array}$} & Intrapersonal & $9 / 32$ & $4 / 09$ & $4 / 09$ & $0 / 04$ \\
\hline & Interpersonal & $25 / 71$ & $16 / 16$ & $16 / 16$ & $0 / 0005$ \\
\hline & Adaptability & $2 / 56$ & $10 / 56$ & $10 / 56$ & $0 / 004$ \\
\hline & Stress management & $112 / 51$ & $8 / 73$ & $8 / 73$ & $0 / 006$ \\
\hline & General mood & $52 / 32$ & $15 / 20$ & $15 / 20$ & $0 / 0005$ \\
\hline & Positive impression & $4 / 55$ & $13 / 15$ & $13 / 15$ & $0 / 0005$ \\
\hline
\end{tabular}


Between group subject effect was evaluated in order to find out whether there has been any differences in changes of average of subscales of emotional intelligence questioners in two experimental and control groups or not. Of course, equality between data error variance matrix was evaluated in both experimental and control groups before doing this analysis and the results of Levine test showed that assumption of Equality of error variances matrix these scores is established. Comparing the experimental and control groups showed that these are different at a significant level in stress management subscale, while these two groups are not different in any other subscale. These findings mean that differences of trend of changes between control and experimental groups has been due to the effect of intervention only in average of stress management subscale.

Table 7. Data of tests between-group effect means of subscales

\begin{tabular}{lccccc}
\hline Subscale & Third type of squares & Degrees of freedom & F ratio & Level Significant & Size Effect \\
\hline Intrapersonal & $0 / 78$ & 1 & $0 / 18$ & $68 / 0$ & $0 / 008$ \\
Interpersonal & $3 / 22$ & 1 & $0 / 32$ & $0 / 58$ & $0 / 01$ \\
Adaptability & $6 / 18$ & 1 & $1 / 17$ & $0 / 29$ & $0 / 05$ \\
Stress management & $13 / 70$ & 1 & $6 / 31$ & $0 / 02$ & $0 / 23$ \\
General mood & $3 / 54$ & 1 & $0 / 58$ & $0 / 45$ & $0 / 03$ \\
Positive impression & $3 / 29$ & 1 & $1 / 87$ & $0 / 19$ & $0 / 08$ \\
\hline
\end{tabular}

\section{Discussion}

In order to evaluate the effectiveness of emotional intelligence training program, this program was implemented on eleven single parent teenagers with emotional and behavioral problems. Data analysis research indicates the effect of the training on increasing Emotional Intelligence of subjects. The statistical results showed that the average scores of single parent teenagers with emotional and behavioral problems participation in the program of emotional intelligence training (experimental group) at post-test were significantly higher than control group participants. According to Table 3, there is an increase in average of subjects in subscales of emotional intelligence questionnaire while these changes are not very noticeable in the control group. In fact, the average of two experimental and control groups in subscales indicate the increase in average of almost all subscales of the experimental group after training courses (Post-test) and slight decrease of some of the scales in the follow-up stage. While, the control groups almost shows no changes in almost none of subscales in all three stages so that the average total emotional intelligence of experimental group in pre-test $(M=15 / 71)$ and post-test $(M=28 / 30)$ also shows this increase in results without performing analytical test. Thus, it can be concluded that Emotional intelligence training program in this research has been able to significantly enhance Emotional intelligence. Several other studies have also achieved a result similar to the mentioned result (Clarke, 2010; Durlak, Weissberg, Dymnicki, Taylor, \& Schellinger, 2011; Qualter \& Gardner, 2012; Shani yailagh, Maktabi, Shokrkon, Haghighi, \& Kianpoor, 2009; Schutte, Malouff, \& Thorsteinsson, 2013). The present research is in line with the mentioned researches and has shown that Emotional Intelligence can be changed and increased. Several important notes can be among the reasons for this increase and skills and among factors affecting the increase of emotional intelligence. In fact, it seems that the researcher has able by identification emotional intelligence training needs of participants and the background select the right skills for training. Skills that were taught in the interventional program of the present research are emotional self-awareness, empathy, assertiveness, interpersonal relations, impulse and anger control, stress management, conflict management and optimism.

Researchers have shown that the effect of intervention programs related to emotional intelligence is also visible in the long term. According to Bar-On Emotional intelligence questionnaire, emotional intelligence scores of the experimental group was higher in follow-up compared to pre-test (even though slight). Data related to this research showed that there is a significant difference at the significance level between emotional intelligence scores at pre-test and follow-up in the experimental group based on emotional intelligence questionnaire which shows sustainability of effectiveness of the program in the follow-up. The main reason for the sustainability of the results is that some of the psychological constructs such as emotional intelligence change over time in the form of process and changes in those requires experience alongside the implementation of intervention programs. Reuben, Sapienza and Zingales's research (2009) and Nelson (2013) can be referred to in this regard. 
It can be understood based on Table 7 that Effectiveness of Emotional Intelligence program on Emotional Intelligence single parent teenagers with emotional and behavioral problems has difference in stress management subscale at the significant level. There are preliminary evidences which indicate that having management skills and being able to regulate self-emotions and emotions of others have protective effect against negative impact of stress and people with high emotional abilities have less stress (Arndt, 2014; Davis, 2012). It seems that improving emotional skills and abilities is essential for this group of teenagers due their importance in social interactions because emotions are in service of social functions, communication and transfer of information about the thoughts and intentions of others. Accordingly, people need emotional information processing and management to lead the social world, have Positive relationships with others and have less conflict. Proper understanding of self-emotions and emotions of others and empathy as the main components of emotional intelligence will make interpersonal communications deeper and it will increase protections, expression of feelings and receiving help from others which will lead to increased mental health and social adjustment (Bar-On, 2010). Limitations of this study were the facts that this study was not Hawthorne controlled because it might have led participants to show reactions different from natural conditions and being in experimental conditions would have probably required more attention and motivation and materialized friendly response which could threaten the generalizability of the results and external validity. Also, the use of these tests in the pre-test, post-test and follow-up can make the transition effect and provoke the sensitivity of participants, thus, it is suggested to researchers to evaluate the effect of emotional intelligence intervention program in different subjects and use different intervention programs for better control of confounding variables and increasing reliability with longer follow-up periods.

\section{Reference}

Achenbach, T., \& Rescorl, L. (2011). Booklet of Manual School Forms Achenbach System of Empirically Based Assessment (A. Minaee, Trans.). Tehran: Education Department.

Al-Said, T. B. T., Birdsey, N., \& Stuart-Hamilton, I. (2013). Psychometric properties of Bar-On emotional quotient inventory youth version among Omani children. International Journal of Learning Management Systems, 1(2), 13-24. https://dx.doi.org/10.12785/ijlms/010202

Arndt. J. E., \& Fujiwara, E. (2014). Interactions between emotion regulation and mental health. Journal of Psychiatry and Behavioral Sciences, 1(5), 8-16.

Bar-On, R. (2010). Emotional intelligence: An integral part of positive psychology. South African. Journal of Psychology, 40(1), 54-62. https://dx.doi.org/10.1177/008124631004000106

Bar-On, R., \& Parker, J. D. A. (2000). The Bar-On Emotional Quotient Inventory: Youth Version (EQ-i: YV). Technical Manual, Toronto, Canada: Multi-Health Systems.

Beh-Pajooh, A., Shokoohi Yekta, M., Motamedi, F., Afrooz, G. A., \& Ghobari Bonab, B. (2015). Psychometrics properties of the Bar-On Emotional Quotient Inventory-Youth version. Journal Research in Educational Systems, 9(30), 7-28.

Carlson, M. J., \& Corcoran, M. E. (2001). Family structure and children's behavioral and cognitive outcomes. Journal of Marriage and Family, 63, 779-792. https://dx.doi.org/10.1111/j.1741-3737.2001.00779.x

Ciairano, S., Bosma, A., Miceli, R., \& Settanni, M. (2008). Adolescent substance use in two European countries: Relationships with psychosocial adjustment, peers, and activities. International Journal of Clinical and Health Psychology, 8(1), 119-138.

Clarke, N. (2010). The impact of a training program designed to target the emotional intelligence abilities of project managers. International Journal of Project Management, 28, 461-468. https://dx.doi.org/10.1016/j.jproman.2009.08.004

Cohen, J. (1988). Statistical Power Analysis for the Behavioral Sciences (2nd ed.). Hillsdale, NJ: Lawrence Earlbaum Associates.

Davis, S. K., \& Humphrey, N. (2012). Emotional intelligence predicts adolescent mental health beyond personality and cognitive ability. Personality and Individual Differences, 52, 144-149. https://dx.doi.org/10.1016/j.paid.2011.09.016

DeLeire, T., \& Kalil, A. (2001). Good things come in threes: Single-parent multigenerational family structure and adolescent adjustment. The Statistical Study of Human Population, 39(2), 393-413. 
Durlak, J. A., Weissberg, R. P., Dymnicki, A. B., Taylor, R. D., \& Schellinger, K. B. (2011). The impact of enhancing students' social and emotional learning: A meta-analysis of school-based universal interventions. Child Development, 82, 405-432. https://dx.doi.org/10.1111/j.1467-8624.2010.01564.x

Esturgo-Deu, M. E., \& Sala-Roca, J. (2010). Disruptive behaviour of students in primary education and emotional intelligence. Teaching and Teacher Education, 26, 830-837. https://dx.doi.org/10.1016/j.tate.2009.10.020

Freedman, G. (2003). Training emotional intelligence and its effect on behavioral problems in high school. Journal of Psychology, 24, 73-80.

Gayathri, N., \& Meenakshi, K. (2013). A literature review of emotional intelligence. International Journal of Humanities and Social Science Invention, 2(3), 42-51.

Meyers, L. S., Gamst, G., \& Guarino, A. (2006). Applied Multivariate Research: Design and Interpretation. Thousand Oaks, CA: Sage.

Minaee, A. (2005). Study of Factor Structure Syndromic Questions of Child Behavior Questionnaire (CBCL) with Using of Confirmatory Factor Analysis. Journal Psychology Education Science, 7, 93-114. (In Persian).

Minaee, A. (2006). Adaptation and Standardization of Child Behavior Checklist, Youth Self-report and Teacher's Report Forms. Research Exceptional Children, 19, 529-558. (In Persian).

Nawi, N. H., \& Redzuan, M. (2011). Emotional intelligence, personality and self esteem: A comparison of the characteristics among two categories of subjects. International Journal of Humanities and Social Science, $1(8), 238-247$.

Nelis, D., Kotsou, I., Quoidbach, J., Hansenne, M., Weytens, F., Dupuis, P., \& Mikolajczak, M. (2011). Increasing emotional competence improves psychological and physical well-being, social relationships, and employability. Emotion, 11, 354-366. https://dx.doi.org/10.1037/a0021554

Nelis, D., Quoidbach, J., Mikolajczak, M., \& Hansenne, M. (2009). Increasing emotional intelligence: (How) is it possible? Personality and Individual Differences, 47, 36-41. https://dx.doi.org/10.1016/j.paid.2009.01.046

Nelson, B. L. (2013). Divorce Mediation and Its Impact on Children. A dissertation submitted in Partial fulfillment of the Requirements for the Degree of Master of Social Work St. Catherine University and the University of St. Thomas St. Paul, Minnesota.

Orme, G. (2003). Emotional intelligence: The cutting edge of interventions in corporate and educational settings. Paper presented on the 29th of May 2003 at the Nexus EQ Conference, Halifax, Nova Scotia, Canada.

Petrides, K. V., Frederickson, N., \& Furnham, A. (2004). The role of trait emotional intelligence in academic performance and deviant behavior at school. Personality and Individual Differences, 36, 277-293. https://dx.doi.org/10.1016/S0191-8869(03)00084-9

Qualter, P., Gardner, K. J., Pope, D. J., Hutchinson, J. M., \& Whiteley, H. E. (2012). Ability emotional intelligence, trait emotional intelligence, and academic success in British secondary schools: A 5 year longitudinal study. Learning and Individual Differences, 22, 83-91. https://dx.doi.org/10.1016/j.lindif.2011.11.007

Reuben, E., Sapienza, P., \& Zingales, L. (2009). Can We Teach Emotional Intelligence? Retrieved April 2, 2013, from http://www.ereuben.net /research/ Teach MSCEIT.pdf

Saadi, Z. E., Honarmand, M. M., Najarian, B., Ahadi, H., \& Askari, P. (2012). Evaluation of the effect of emotional intelligence training on reducing aggression in second year high school female students. Journal of American Science, 8, 209-212.

Schutte, N. S., Malouff, J. M., \& Thorsteinsson, E. B. (2013). Increasing emotional intelligence through training: Current status and future directions. The International Emotional Education, 5(1), 56-72.

Shani Yailagh, M., Maktabi, G., Shokrkon, H., Haghighi, J., \& Kianpoor, F. (2009). Effects of teaching emotional intelligence on social anxiety, social adjustment and emotional intelligence in boy and girl students. Journal of Psychology Achievement, 4(1), 3-26. (In Persian).

Shuler, C, S. (2004). An Analysis of the Emotional Inventory: Youth Version as a Measure of Emotional Intelligence in Children and Adolescents. A Dissertation submitted to the Department of Educational 
Psychology and Learning Systems in partial fulfillment of the requirements for the degree of doctor of Philosophy, The Florida State University College of Education.

Siu, A. F. Y. (2009). Trait emotional intelligence and its relationships with problem behavior in Hong Kong adolescents. Personality and Individual Differences, 47, 553-557. https://dx.doi.org/10.1016/j.paid.2009.05.004

Sternberg, R. (2000). Handbook of Intelligence. Cambridge, UK: Cambridge University Press. https://dx.doi.org/10.1017/CBO9780511807947

Wolfe, D. A., \& Mash, E. J. (2006). Behavioral and emotional disorders in adolescents: Nature, assessment, and treatment. New York, NY, Guilford Press.

\section{Copyrights}

Copyright for this article is retained by the author(s), with first publication rights granted to the journal.

This is an open-access article distributed under the terms and conditions of the Creative Commons Attribution license (http://creativecommons.org/licenses/by/4.0/). 